\title{
Mild spring temperature rising affects the anti-oxidation and immune functions of Asian Short-toed Larks
}

\author{
Na Zhu' ${ }^{1}$, Tingting Liu' ${ }^{1}$, Fei Wang ${ }^{1}$, Wei Liang ${ }^{2}$ and Shuping Zhang ${ }^{1^{*}}$ (D)
}

\begin{abstract}
Background: Predicting the possibility of severe effects of global warming on animals is important for understanding the ecological consequences of climate change on ecosystem. Spring is the season during which birds have to physiologically prepare for the subsequent breeding period, and unusual spring temperature rising probably becomes a heat stress to the birds which have adapted to the low spring temperature. Therefore, it is necessary to understand the physiological effect of spring warming on the temperate birds.

Methods: Using the activities of blood anti-oxidative enzymes (SOD, CAT, GPX) and the concentrations of serum immunogloblins (IgA, IgY, IgM) as indicators, we compared the anti-oxidative and immune functions of Asian Shorttoed Larks (Calandrella cheleensis) captured between 10 and 15 March, 2015 and housed under conditions of $21^{\circ} \mathrm{C}$ and $16^{\circ} \mathrm{C}$.
\end{abstract}

Results: The SOD activities of birds in $21^{\circ} \mathrm{C}$ group were significantly lower than those in $16^{\circ} \mathrm{C}$ group on all the treatment days. The CAT activities of the birds in $21^{\circ} \mathrm{C}$ group were significantly lower than those in $16^{\circ} \mathrm{C}$ group on the $1 \mathrm{st}$, 5th, 13th, 17 treatment days. The GPx activities of the birds in $21^{\circ} \mathrm{C}$ group were signifthicantly lower than those in $16^{\circ} \mathrm{C}$ group on the $1 \mathrm{st}, 13$ th and $17 \mathrm{th}$, but significantly higher on the 21 st treatment day. The IgA, IgY and IgM concentrations of birds in $21^{\circ} \mathrm{C}$ group were significantly lower than those in $16^{\circ} \mathrm{C}$ group on all the treatment days.

Conclusions: This study shows that spring temperature rising negatively influences antioxibative and humoral immune functions, which indicates that spring climate warming might reduce the fitness of the temperate passerine birds which have adapted to the low spring temperature.

Keywords: Mild temperature rising, Anti-oxidant capacity, Immunity, Asian Short-toed Larks, Spring

\section{Background}

Although physiological responses of ectotherms to rising global temperature have received great amount of attention by biogeographers and physiologists (Somero 2010; Tomanek 2010; Folguera et al. 2011), such responses of endotherms have not been fully understood. Heatrelated deaths of birds have been reported in Australia,

*Correspondence: zhangshuping@muc.edu.cn

${ }^{1}$ College of Life and Environment Sciences, Minzu University of China, Beijing 100081, China

Full list of author information is available at the end of the article
India, South Africa and the southwestern USA (Marshall and Serventy 1962; Erasmus et al. 2002; Welbergen et al. 2008; McKechnie et al. 2012). Data on southern African desert birds revealed that a suite of physiological variables change rapidly with increasing air temperatures within the comparatively narrow range of $30-40{ }^{\circ} \mathrm{C}$, far below those typically associated with mortality events (McKechnie et al. 2012). Therefore, predicting the possibility of severe effects of global warming on birds is necessary.

Birds that live at middle and high latitudes experience different temperatures in different seasons, therefore 
many physiological processes such as energy metabolism, stress response, and reproduction in birds significantly change with environmental temperature in different seasons (Wingfield et al. 1982; Silverin et al. 2008; Swanson 2010; Zheng et al. 2014). Spring is the season during which birds have to physiologically prepare for the subsequent breeding period (Stevenson and Bryant 2000; Nilsson and Raberg 2001; Goutte et al. 2010; Hegemann et al. 2012), hence the ability to maintain homeostasis during this period is important to survival and reproduction of birds. Unusual spring temperature rising probably becomes a heat stress to the birds which have adapted to low spring temperature. Therefore, it is necessary to understand the physiological effect of spring warming on the temperate birds.

High temperature has been found to induce increases in the production of reactive oxygen species (ROS) (Flanagan et al. 1998; Mujahid et al. 2005; Lin et al. 2008; Costantini et al. 2012) and thereby induce oxidative stress (Costantini and Verhulst 2009; Azad et al. 2010), which can cause cell damage even to apoptosis (e.g. Kannan and Jain 2000). The vertebrate cells can eliminate ROS through the activition of antioxidant system such as antioxidant enzymes to avoid the damage to the cells (Baxter et al. 2014; Huang et al. 2015). Therefore, anti-oxidation function can reflect the survival ability of birds. In addition, immunal function is another important indicator for survivability of birds. It has been well understood that many environmental stressors especially temperature variation have inhibitory effect on the B-lymphocytemediated humoral immunity through hypothalamicpituitary-adrenal cortex axis (HPA) (Shephard 1998; Sapolsky et al. 2000; Quintana et al. 2011; Habibian et al. 2014; Yang et al. 2015), which is related with the survival of the birds. It has been found in wild birds and chicken that heat stress may reduce the immune function of birds by inhibiting the production of immunoglobulin (Zulkifli et al. 1994; Park et al. 2013). Although there are lots of information about the effects of environment stressors on the antioxidation and immune function, the effects of spring climate warming on these two functions of wild temperate birds have not been well understood. Therefore, it is necessary to evaluate these effects on the temperate wild birds in order to understand the physiological mechanism of the climate change effects on survival of birds.

Whether spring warming affects the antioxidation and immune function of wild temperate birds? To answer this question, we studied antioxidation and immune function in Asian Short-toed Larks (Calandrella cheleensis) distributed in the high-latitude grassland of Inner Mongolia. Asian Short-toed Lark is a resident bird species on the high latitude grassland of China, which initiates breeding in early spring. The species has adapted to the low spring temperature and is vulnerable to the heat stress induced by unusual spring temperature rising (Zhao et al. 2017a). Therfore, we selected this species as a model of this study. We compared activities of anti-oxidative enzymes including super oxide dismutase (SOD), catalase (CAT) and glutathione peroxidase (GPx), and levels of immunoglobulin IgA, IgY and IgM, in samples of peripheral blood cells of captured Asian Short-toed Larks in normal and higher ambient temperature condition by conducting a controlled laboratory experiment.

\section{Methods \\ Study site and species}

The study site was located within the Hulun Lake National Nature Reserve $\left(47^{\circ} 45^{\prime} 50^{\prime \prime} \mathrm{N}-49^{\circ} 20^{\prime} 20^{\prime \prime} \mathrm{N}\right.$; $116^{\circ} 50^{\prime} 10^{\prime \prime} \mathrm{E}-118^{\circ} 10^{\prime} 10^{\prime \prime} \mathrm{E}$ ) situated in the northeastern part of the Inner Mongolian Autonomous Region, China. This reserve is a semiarid, steppe region where the mean annual temperature, precipitation and potential evaporation are $-0.6{ }^{\circ} \mathrm{C}, 283 \mathrm{~mm}$ and $1754 \mathrm{~mm}$, respectively. Winter is longer than summer, and the average maximum daytime temperatures in January and July are $-20.02{ }^{\circ} \mathrm{C}$ and $22.72{ }^{\circ} \mathrm{C}$, respectively. Spring is in March and April. The Asian Short-toed Lark (Calandrella cheleensis, Passeriformes, Alaudidae) is the most common lark species on the grasslands of the study site. The birds used in this study were captured in the study site between 10 and 15 March, 2015.

\section{Experiment design}

Two air-conditioned, temperature-controlled chambers were built at the study site. Forty adult Asian Short-toed Larks were randomly assigned to these chambers, with 20 birds to each chamber (sex ratio 1:1). All birds were housed in individual cages $(50 \mathrm{~cm} \times 40 \mathrm{~cm} \times 35 \mathrm{~cm})$ within each temperature chamber, and they were fed mixed seeds, boiled eggs and mealworms, and provided with water ad libitum. Considering the physiological status of birds could be influenced by captivity (Li et al. 2019), we initially kept both chambers at $16{ }^{\circ} \mathrm{C}$ under a 16:8-h light:dark photoperiod for 10 days to allow the birds to acclimatize. At the end of this 10-day period we increased the temperature of one chamber to $21^{\circ} \mathrm{C}$, while the temperature of the other was kept at $16^{\circ} \mathrm{C}$. This temperature treatment regime was continued for 21 days. The choice of $16^{\circ} \mathrm{C}$ as the lower temperature was based on the mean daily maximum temperature recorded at the study site in April 2014. As the mean daily temperature difference between sample days during the field experiment period was about $5{ }^{\circ} \mathrm{C}$, we chose $21^{\circ} \mathrm{C}$ as the higher temperature. At least $50 \mu \mathrm{L}$ of whole blood was collected from each bird at 4-day intervals at 12:00-12:30 h over 
the experimental period to measure the levels of anti-oxidation enzymes CAT, SOD, GPx and immunoglobulins IgA, IgY, IgM.

\section{Anti-oxidation enzyme analysis}

The activities of three enzymes SOD, CAT and GPx were measured using commercial kits (Nanjing Jiancheng Bioengineering Institute, Nanjing, China). SOD activity was measured using the xanthine/xanthine oxidase method based on the production of $\mathrm{O}^{2-}$ anions. GPx activity was measured based on its catalyzation by the oxidation of reduced glutathione in the presence of cumene hydroperoxide. The generation of nicotinamide adenine dinucleotide phosphate was measured spectrophotometrically at $340 \mathrm{~nm}$. CAT activity was measured by analyzing the rate at which it caused the decomposition of $\mathrm{H}_{2} \mathrm{O}_{2}$ at $240 \mathrm{~nm}$.

\section{Immunoglobulin analysis}

IgA, IgY and IgM concentrations were determined using chicken enzyme immunoassay (ELISA) kits from Nanjing Jiancheng Bioengineering Institute (Nanjing, China). Briefly, all serum samples were 1:5 diluted $(10 \mu \mathrm{L}$ of the sample and $40 \mu \mathrm{L}$ of the sample dilution) and added to sample wells in triplicates. The standard wells and the sample wells were added with $100 \mu \mathrm{L}$ of detection antibody which were marked by horseradish peroxidase (HRP) and incubated for $60 \mathrm{~min}$ at $37^{\circ} \mathrm{C}$. Then the plates were washed five times with PBS. Some $50 \mu \mathrm{L}$ of substrate $\mathrm{A}$ and $\mathrm{B}$ were added to plates and incubated for $15 \mathrm{~min}$ at $37^{\circ} \mathrm{C}$. Finally, $50 \mu \mathrm{L}$ of stop solution was added to each well, and the OD value of each well at a wavelength of $450 \mathrm{~nm}$ was measured within $15 \mathrm{~min}$ by microplate reader (Thermo company, USA). The respective inter- and intra-plate coefficients of variation for IgA, IgY and IgM were $<12 \%$.

\section{Data analysis}

We used linear mixed models (LMMs) to analyze the effects of temperature, sex, body mass and their interactions on plasma SOD, CAT, GPx activities and IgA, IgY, and IgM concentrations. Temperature, sex, body mass, and the interactions between these factors were modeled as fixed factors, with individual as a random factor. All data were log transformed to correct for departures from nor- mality and homogeneity of variance. All data analyses were performed using SPSS version 18.0 and $\alpha=0.05$ in all tests.

\section{Results}

The activities of plasma SOD, CAT and GPx in Asian

Short-toed Larks

The LMM results indicated that temperature significantly influenced the blood SOD, CAT and GPx activities of Asian Short-toed Larks (Table 1). The SOD activitiy of birds in $21{ }^{\circ} \mathrm{C}$ group was significantly lower than that in $16^{\circ} \mathrm{C}$ group on all the treatment days (Independent sample $t$ test, $n=20, P<0.05$, Fig. 1a). The CAT activity of the birds in $21{ }^{\circ} \mathrm{C}$ group was significantly lower than that in $16^{\circ} \mathrm{C}$ group on the 1 st, 5 th, 13th, 17th treatment days (Independent sample $t$-test, $n=20, P<0.05$, Fig. $1 b)$. The GPx activity of the birds in $21^{\circ} \mathrm{C}$ group was significantly lower than that in $16^{\circ} \mathrm{C}$ group on the 1st, 13th and 17th, but significantly higher on the 21st treatment day (Independent sample $t$-test, $n=20, P<0.05$, Fig. 1 c).

\section{The concentrations of serum $\lg \mathrm{A}, \lg \mathrm{Y}$ and $\lg \mathrm{M}$ in Asian Short-toed Larks}

The LMM results indicated that temperature significantly influenced the plasma IgA, IgY and IgM concentrations of Asian Short-toed Larks (Table 2). The serum IgA, IgY and IgM concentrations of birds in $21^{\circ} \mathrm{C}$ group were significantly lower than those in $16{ }^{\circ} \mathrm{C}$ group on all the treatment days (Independent $t$-test, $n=20, P<0.05$, Fig. 2).

Table 1 Results of a linear mixed model for the effects of temperature, sex, body mass, on blood CAT, SOD, GPX activities in wild Asian Short-toed Larks (Calandrella cheleensis) captured in Hulun Lake Nature Reserve, Inner Mongolia, China

\begin{tabular}{llrr}
\hline $\begin{array}{l}\text { Response } \\
\text { variable }\end{array}$ & Explanatory variable & \multicolumn{1}{l}{$\boldsymbol{l}$} \\
\hline CAT & Temperature & 14.481 & $<0.001$ \\
& Sex & 1.701 & 0.196 \\
& Body mass & 0.081 & 0.776 \\
& Temperature $\times$ sex & 1.779 & 0.141 \\
& Temperature $\times$ body mass & 0.703 & 0.404 \\
SOD & Sex $\times$ body mass & 0.702 & 0.593 \\
& Temperature & 136.056 & $<0.001$ \\
& Sex & 3.816 & 0.057 \\
& Body mass & 3.816 & 0.057 \\
& Temperature $\times$ sex & 3.020 & 0.058 \\
& Temperature $\times$ body mass & 1.401 & 0.242 \\
GPx & Sex $\times$ body mass & 2.650 & 0.081 \\
& Temperature & 5.992 & 0.040 \\
& Sex & 0.082 & 0.776 \\
& Body mass & 0.414 & 0.523 \\
& Temperature $\times$ sex & 0.055 & 0.815 \\
& Temperature $\times$ body mass & 1.015 & 0.370 \\
& Sex $\times$ body mass & 0.178 & 0.837 \\
\hline
\end{tabular}

$P$ values in italics indicate that the explanatory variables significantly influence the response variables 


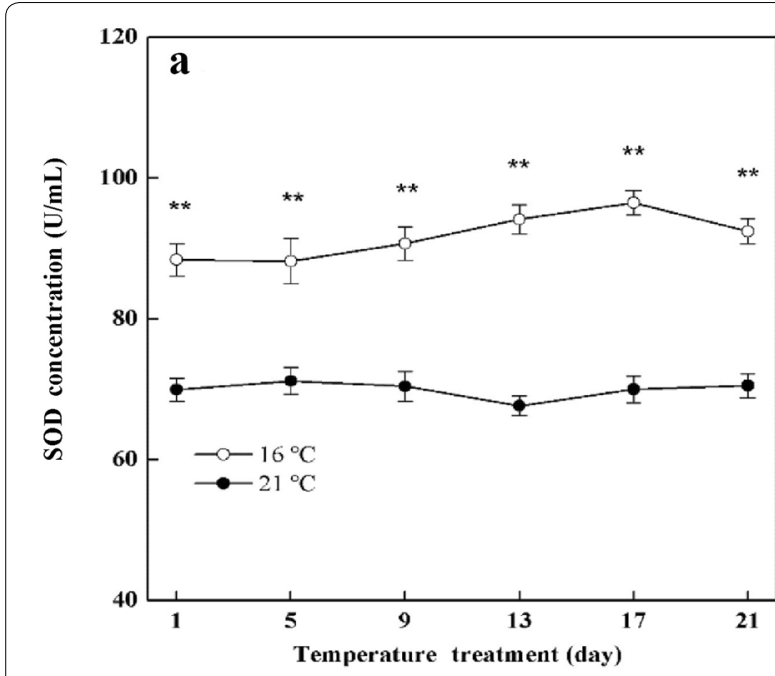

Table 2 Results of a linear mixed model for the effects of temperature, sex, body mass, on plasma $\operatorname{lgA}$, $\lg Y$ and IgM activities in wild Asian Short-toed Larks (Calandrella cheleensis) captured in Hulun Lake Nature Reserve, Inner Mongolia, China

\begin{tabular}{llrr}
\hline $\begin{array}{l}\text { Response } \\
\text { variable }\end{array}$ & Explanatory variable & \multicolumn{1}{l}{$\boldsymbol{F}$} & \multicolumn{1}{l}{$\boldsymbol{P}$} \\
\hline IgA & Temperature & 10.948 & $<0.001$ \\
& Sex & 0.009 & 0.924 \\
& Body mass & 0.927 & 0.403 \\
& Temperature $\times$ sex & 0.000 & 0.997 \\
& Temperature $\times$ body mass & 0.958 & 0.391 \\
IgY & Sex $\times$ body mass & 0.515 & 0.600 \\
& Temperature & 40.853 & $<0.001$ \\
& Sex & 0.635 & 0.429 \\
& Body mass & 0.603 & 0.551 \\
& Temperature $\times$ sex & 0.104 & 0.748 \\
& Temperature $\times$ body mass & 0.192 & 0.826 \\
& Sex $\times$ body mass & 1.045 & 0.359 \\
IgM & Temperature & 17.386 & $<0.001$ \\
& Sex & 2.471 & 0.123 \\
& Body mass & 1.381 & 0.261 \\
& Temperature $\times$ sex & 0.097 & 0.757 \\
& Temperature $\times$ body mass & 0.253 & 0.777 \\
& Sex $\times$ body mass & 0.198 & 0.821 \\
\hline
\end{tabular}

$P$ values in italics indicate that the explanatory variables significantly influence the response variables

\section{Discussion}

The results that activities of antioxidative enzymes SOD, CAT and GPx in the blood of Asian Short-toed Larks decreased significantly at $21{ }^{\circ} \mathrm{C}$ indicate that mild temperature rising can inhibit the antioxidative function of Asian Short-toed Larks distributed in high latitude grassland which have adapted to relatively low temperature in spring. Antioxidant enzymes play a vital role in protecting cellular damage from harmful effects of ROS (Baxter et al. 2014; Huang et al. 2015) and it has been found that heat stress can increase lipid peroxidation (Altan et al. 2003; Lin et al. 2008; Altan et al. 2010), therefore reduced oxidative protection can result in increased oxidative damage and fitness costs.

In addition, Asian Short-toed Larks start to breed in early spring (April), while breeding is an energy consuming process which will produce more oxygen free radicals than non-breeding period (Wiersma et al. 2004). Moreover, the negative relationships between brood size and activity of antioxidative enzymes have been found in bird species (Alonso-Álvarez et al. 2010). Therefore, the spring temperature rising together with breeding efforts will aggravate oxidative damage on birds. Our results implicate that birds which have adapted to the low spring

Fig. 1 Blood SOD (a), CAT (b) and GPX (c) activities of Asian Short-toed Larks in $21^{\circ} \mathrm{C}$ and $16^{\circ} \mathrm{C}$ treatment groups 

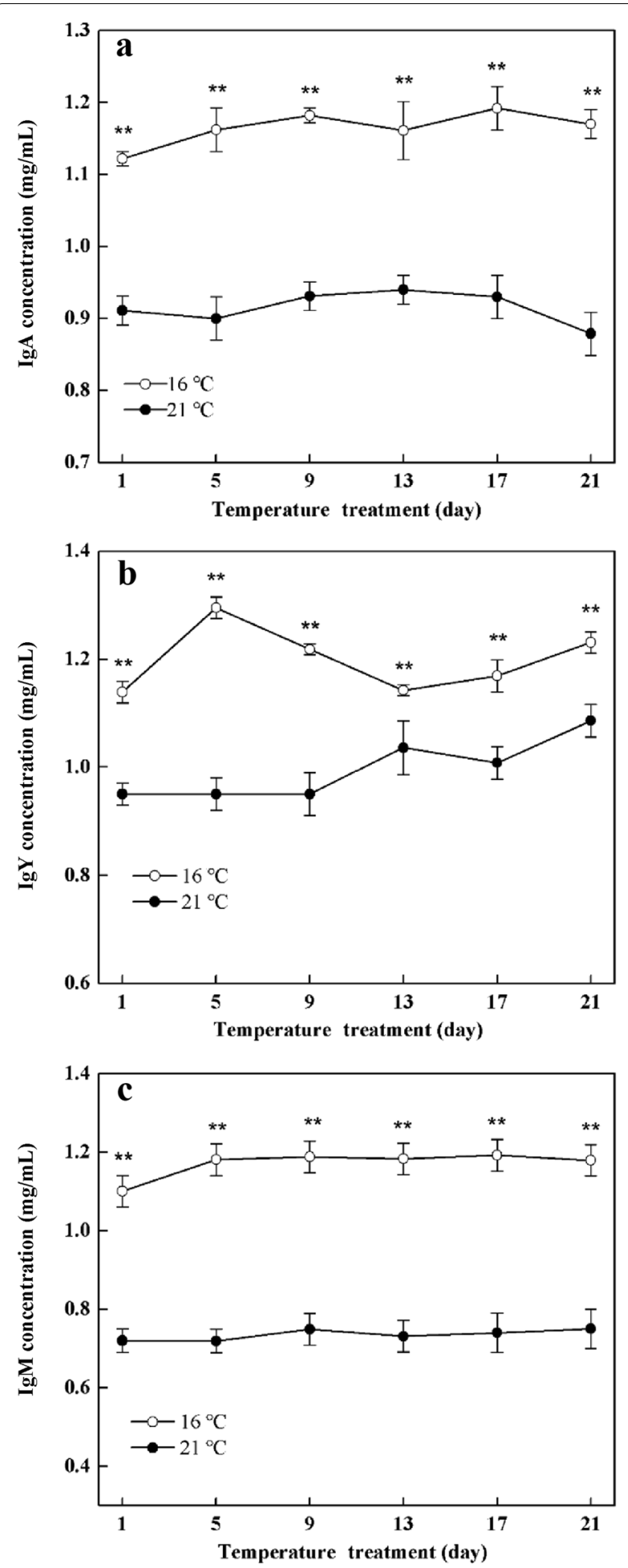

Fig. 2 Serum $\lg A(\mathbf{a}), \lg Y(\mathbf{b})$ and $\lg M(\mathbf{c})$ concentrations of Asian Short-toed Larks in $21^{\circ} \mathrm{C}$ and $16^{\circ} \mathrm{C}$ treatment groups temperature will be susceptible to the spring climate warming. Meanwhile, we cannot neglect the result that GPx at $21{ }^{\circ} \mathrm{C}$ is significantly higher than that at $16{ }^{\circ} \mathrm{C}$ on the 21st treatment day, which implicates that the antioxidative function of the cells may revover partially after long time acclimation. A previous study on Asian Shorttoed Larks showed that marked daily variations in ambient temperature in spring can activate apoptosis protein Caspase-3 expression in the cells of Asian Short-toed Larks while the Bcl-2 and HSP60 can maintain cellular homeostasis (Qin et al. 2017). Therefore, the HSPs' protection on the cell might be related with the variation of GPx, and the mechanism should be varified in the future.

Although immunoglobulin decreasing induced by heat stress has been found in domestic chicken (Chin et al. 2013), the effects of mild temperature rising on the immunity on wild birds in spring have not been well known. Our results that the concentration of immunoglobulins IgA, IgY and IgM in the serum of Asian Short-toed Larks decreased significantly at $21{ }^{\circ} \mathrm{C}$ indicate that temperature rising can reduce the B-lymphocyte-mediated humoral immunity of Asian Short-toed Larks in spring. A wild bird study on Eurasian Tree Sparrow (Passer montanus) found that the plasma IgA level is higher in winter than in breeding season (Zhao et al. 2017b), which supports the above deduction from our results. The concentration of immunoglobulins in serum can reflect the disease resistance of the body (Peppas et al. 2019). IgA, IgY and IgM are three important immunoglobulins in birds. IgA is an important barrier of respiratory mucosa (Rose et al. 1974; Kaspers et al. 1996; Bencina et al. 2005; Bar-Shira et al. 2014). IgY is a functional homolog of mammalian IgG and has been found to efficiently opsonize pathogens for engulfment by phagocytes (Huang et al. 2016). IgM has many functions such as precipitation and agglutination (Díaz-Zaragoza et al. 2015; Atif et al. 2018; Peppas et al. 2019). Therefore, reduction of these immunoglobulins can lead to the decrease or inhibition of humoral immunity. To the wild birds, there is an trade-off between innate immunity and acquired immunity in different ecological conditions (Zhao et al. 2017b), therefore the innate immunity should be combined to evaluate the immunity vulnerability of birds to temperature in natural condition.

The immunoglobulin reduction in the birds treated by $21^{\circ} \mathrm{C}$ may be related with the HSPs expression (Qin et al. 2017). The HSPs can maintain the homeostasis of the cells, overexpression of HSPs, however, is known to have deleterious consequences (Feder and Hofmann 1999). Synthesis of HSPs represents a significant energetic cost (Hamdoun et al. 2003), therefore their response usually results in a concomitant reduction in the synthesis of antibodies. Synthesizing more HSPs to mitigate stress 
has been found in passerine birds to be traded-off against mounting humoral and cell-mediated immune responses (Morales et al. 2006). The available results jointly indicate that mild temperature rising in spring can induce cell stress response, which could subsequently induce the immune function reduction.

Our results suggest that mild spring temperature rising can lead to the reduction of antioxidative and immune functions of temperate passerine birds. Under the climate warming scenario, discriminating the climate susceptible species is urgent (Glover 2018). The species with narrow environmental tolerances or thresholds are likely to be susceptible to the climate warming at any stage in the life cycle. It is important, therefore, to investigate physiological responses to global warming in more terrestrial vertebrates in different thermal environments to assess the potential threat of global warming-induced heat stress to biodiversity.

\section{Conclusion}

In summary, this study shows that spring temperature rising negatively influences antioxibative and humoral immune functions, which indicates that spring climate warming might reduce the fitness of the temperate passerine birds which have adapted to the low spring temperature.

\section{Acknowledgements}

We are grateful to Manquan Gui, Muren Wu, Songtao Liu in Hulun Lake National Nature Reserve for their help on the field study.

\section{Authors' contributions}

SZ and WL conceived the study and designed the experiments. NZ, FW and $T L$ conducted the experiments. NZ wrote the first draft of the article. SZ supervised the research and revised the draft. All authors read and approved final manuscript.

\section{Funding}

This study was supported by the National Natural Science Foundation of China (No. 31872246).

\section{Availability of data and materials}

The data used in the present study are available from the corresponding author on reasonable request.

\section{Ethics approval and consent to participate}

Our experimental procedures complied with the current laws on animal welfare and research in China and had the approval of the Animal Research Ethics Committee of Hainan Normal University. In addition, all procedures followed standard protocols, such as the ARRIVE guidelines for reporting animal research.

\section{Consent for publication}

Not applicable.

\section{Competing interests}

The authors declare that they have no competing interests.

\section{Author details}

${ }^{1}$ College of Life and Environment Sciences, Minzu University of China, Beijing 100081, China. ${ }^{2}$ Ministry of Education Key Laboratory for Ecology of Tropical Islands, College of Life Sciences, Hainan Normal University, Haikou 571158, China.

Received: 18 November 2019 Accepted: 26 April 2020

Published online: 30 April 2020

\section{References}

Alonso-Álvarez C, Pérez-Rodríguez L, Garcia JT, Vinuela J, Mateo R. Age and breeding effort as sources of individual variability in oxidative stress markers in a bird species. Physiol Biochem Zool. 2010;83:110-8.

Altan N, Se-Dinc A, Sahin D, Kocamanoglu N, Kosova F, Engin A. Oxidative DNA damage: the thyroid hormone-mediated effects of insulin on liver tissue. Endocrine. 2010;38:214-20.

Altan O, Pabuccuoglu A, Altan A, Konyalioglu S, Bayraktar H. Effect of heat stress on oxidative stress, lipid peroxidation and some stress parameters in broilers. Poult Sci. 2003;44:545-50.

Atif SM, Gibbings SL, Redente EF, Camp FA, Torres RM, Kedl RM, et al. Immune surveillance by natural lgM is required for early neoantigen recognition and initiation of adaptive immunity. Am J Respir Cell Mol Biol. 2018:59:580-91.

Azad MA, Kikusato M, Maekawa T, Shirakawa H, Toyomizu M. Metabolic characteristics and oxidative damage to skeletal muscle in broiler chickens exposed to chronic heat stress. Comp Biochem Physiol A. 2010;155:401-6.

Bar-Shira E, Cohen I, Elad O, Friedman A. Role of goblet cells and mucin layer in protecting maternal IgA in precocious birds. Dev Comp Immunol. 2014:44:186-94.

Baxter A, Mittler R, Suzuki N. ROS as key players in plant stress signalling. J Exp Bot. 2014:65:1229-40.

Bencina D, Narat M, Bidovec A, Zorman-Rojs O. Transfer of maternal immunoglobulins and antibodies to Mycoplasma gallisepticum and Mycoplasma synoviae to the allantoic and amniotic fluid of chicken embryos. Avian Pathol. 2005;34:463-72.

Chin EH, Quinn JS, Burness G. Acute stress during ontogeny suppresses innate, but not acquired immunity in a semi-precocial bird (Larus delawarensis). Gen Comp Endocrinol. 2013;193:185-92.

Costantini D, Ferrari C, Pasquaretta C, Cavallone E, Carere C, von Hardenberg A, et al. Interplay between plasma oxidative status, cortisol and coping styles in wild alpine marmots Marmota marmota. J Exp Biol. 2012;215:374-83.

Costantini $D$, Verhulst $S$. Does high antioxidant capacity indicate low oxidative stress? Func Ecol. 2009:23:506-9.

Díaz-Zaragoza M, Hernández-Ávila R, Viedma-Rodríguez R, Arenas-Aranda D, Ostoa-Saloma P. Natural and adaptive IgM antibodies in the recognition of tumor-associated antigens of breast cancer (Review). Oncol Rep. 2015:34:1106-14.

Erasmus BFN, Van Jaarsveld AS, Chown SL, Kshatriya M, Wessels KJ. Vulnerability of South African animal taxa to climate change. Global Change Biol. 2002:8:679-93.

Feder ME, Hofmann GE. Heat-shock proteins, molecular chaperones, and the stress response: evolutionary and ecological physiology. Annu Rev Physiol. 1999;61:243-82.

Flanagan SW, Moseley PL, Buettner GR. Increased flux of free radicals in cells subjected to hyperthermia: detection by electron paramagnetic resonance spin trapping. FEBS Lett. 1998:431:285-6.

Folguera G, Bastias DA, Caers J, Rojas JM, Piulachs MD, Belles X, et al. An experimental test of the role of environmental temperature variability on ectotherm molecular, physiological and life-history traits: implications for global warming. Comp Biochem Physiol A Mol Integr Physiol. 2011;159:242-6.

Glover CN. Defence mechanisms: the role of physiology in current and future environmental protection paradigms. Conserv Physiol. 2018;6:Coy012.

Goutte A, Angelier F, Chastel CC, Trouve C, Moe B, Bech C, et al. Stress and the timing of breeding: glucocorticoid-luteinizing hormones relationships in an arctic seabird. Gen Comp Endocrinol. 2010;169:108-16.

Habibian M, Ghazi S, Moeini MM, Abdolmohammadi A. Effects of dietary selenium and vitamin E on immune response and biological blood parameters of broilers reared under thermoneutral or heat stress conditions. Int J Biometeorol. 2014;58:741-52. 
Hamdoun AM, Cheney DP, Cherr GN. Phenotypic plasticity of HSP70 and HSP70 gene expression in the Pacific oyster (Crassostrea gigas): implications for thermal limits and induction of thermal tolerance. Biol Bull. 2003;205:160-9.

Hegemann A, Matson KD, Versteegh MA, Tieleman BI. Wild skylarks seasonally modulate energy budgets but maintain energetically costly inflammatory immune responses throughout the annual cycle. PLOS ONE. 2012;7:e36358.

Huang C, Jiao H, Song Z, Zhao J, Wang X, Lin H. Heat stress impairs mitochondria functions and induces oxidative injury in broiler chickens. J Anim Sci. 2015;93:2144-53

Huang T, Wu K, Yuan X, Shao S, Wang W, Wei S, et al. Molecular analysis of the immunoglobulin genes in goose. Dev Comp Immunol. 2016;60:160-6.

Kannan K, Jain SK. Oxidative stress and apoptosis. Pathophysiology. 2000;7:153-63.

Kaspers B, Bondl H, Göbel TWF. Transfer of IgA from albumen into the yolk sac during embryonic development in the chicken. J Vet Med A. 1996:43:225-31.

Li M, Zhu WW, Wang Y, Sun YF, Li JY, Liu XL, et al. Effects of capture and captivity on plasma corticosterone and metabolite levels in breeding Eurasian tree sparrows. Avian Res. 2019;10:16.

Lin H, De Vos D, Decuypere E, Buyse J. Dynamic changes in parameters of redox balance after mild heat stress in aged laying hens (Gallus gallus domesticus). Comp Biochem Physiol C Toxicol Pharmacol. 2008;147:30-5.

Marshall AJ, Serventy DL. Inheritance and neuroendocrine adaptations in birds. Gen Comp Endocr. 1962;1:217-26.

McKechnie AE, Hockey PAR, Wolf BO. Feeling the heat: Australian landbirds and climate change. Emu. 2012;112:i-vii.

Morales-Suarez-Varela MM, Olsen J, Johansen P, Kaerlev L, Guenel P, Arveux $P$, et al. Occupational sun exposure and mycosis fungoides: a European multicenter case-control study. J Occup Environ Med. 2006:48:390-3.

Mujahid A, Yoshiki Y, Akiba Y, Toyomizu M. Superoxide radical production in chicken skeletal muscle induced by acute heat stress. Poultry Sci. 2005;84:307-14

Nilsson JA, Raberg L. The resting metabolic cost of egg laying and nestling feeding in great tits. Oecologia. 2001;128:187-92.

Park S, Hwangbo J, Ryu CM, Park BS, Chae HS, Choi HC, et al. Effects of extreme heat stress on growth performance, lymphoid organ, lgY and cecum microflora of broiler chickens. Int J Agric Biol. 2013;15:1204-8.

Peppas I, Sollie S, Josephs DH, Hammar N, Walldius G, Karagiannis SN, et al. Serum immunoglobulin levels and the risk of bladder cancer in the AMORIS Cohort. Cancer Epidemiol. 2019:62:101584.

Qin X, Liu T, Zhao L, Liang W, Zhang S. Marked daily variation in spring temperature induces variation in Caspase-3, Bcl-2 and HSP60 in Asian Short-toed Larks: how do wild birds maintain cellular homeostasis to cope with the ambient temperature variation? J Ornithol. 2017;158:1025-34.
Quintana FJ, Cohen IR. The HSP60 immune system network. Trends Immunol. 2011;32:89-95.

Rose ME, Orlans E, Buttress N. Immunoglobulin classes in the hen's egg: their segregation in yolk and white. Eur J Immunol. 1974;4:521-3.

Sapolsky RM, Romero L, Munck AU. How do glucocorticoids influence stress responses? Integrating permissive, suppressive, stimulatory, and preparative actions. Endocr Rev. 2000;21:55-89.

Silverin B, Wingfield J, Stokkan KA, Massa R, Jarvinen A, Andersson NA, et al. Ambient temperature effects on photo induced gonadal cycles and hormonal secretion patterns in Great Tits from three different breeding latitudes. Horm Behav. 2008;54:60-8.

Somero GN. The physiology of climate change: how potentials for acclimatization and genetic adaptation will determine 'winners' and 'losers'. J Exp Biol. 2010;213:912-20.

Stevenson IR, Bryant DM. Climate change and constraints on breeding. Nature. 2000;406:366-7.

Swanson DL. Seasonal metabolic variation in birds: functional and mechanistic correlates. Curr Ornithol. 2010;17:75-129.

Tomanek L. Variation in the heat shock response and its implication for predicting the effect of global climate change on species' biogeographical distribution ranges and metabolic costs. J Exp Biol. 2010;213:971-9.

Welbergen JA, Klose SM, Markus N, Eby P. Climate change and the effects of temperature extremes on Australian flying-foxes. Proc R Soc B. 2008:275:419-25.

Wiersma P, Selman C, Speakman JR, Verhulst S. Birds sacrifice oxidative protection for reproduction. Proc R Soc Lond B. 2004;271:S360-3.

Wingfield JC, Smith JP, Farner DS. Endocrine responses of White-crowned Sparrows to environmental stress. Condor. 1982;84:399-409.

Yang J, Liu L, Sheikhahmadi A, Wang Y, Li C, Jiao H, et al. Effects of corticosterone and dietary energy on immune function of broiler chickens. PLoS ONE. 2015;10:e0119750.

Zhao L, Gao L, Yang W, Xu X, Wang W, Liang W, et al. Do migrant and resident species differ in the timing of increases in reproductive and thyroid hormone secretion and body mass? A case study in the comparison of pre-breeding physiological rhythms in the Eurasian Skylark and Asian Short-toed Lark. Avian Res. 2017a;8:10.

Zhao Y, Li M, Sun Y, Wu W, Kou G, Guo L, et al. Life-history dependent relationships between body condition and immunity, between immunity indices in male Eurasian tree sparrows. Comp Biochem Phys A. 2017b;210:7-13.

Zheng WH, Li M, Liu JS, Shao SL, Xu XJ. Seasonal variation of metabolic thermogenesis in Eurasian tree sparrows (Passer montanus) over a latitudinal gradient. Physiol Biochem Zool. 2014;87:704-18.

Zulkifli I, Dunnington EA, Gross WB, Siegel PB. Inhibition of adrenal steroidogenesis, food restriction and acclimation to high ambient temperatures in chickens. Poult Sci. 1994;35:417-26.
Ready to submit your research? Choose BMC and benefit from:

- fast, convenient online submission

- thorough peer review by experienced researchers in your field

- rapid publication on acceptance

- support for research data, including large and complex data types

- gold Open Access which fosters wider collaboration and increased citations

- maximum visibility for your research: over $100 \mathrm{M}$ website views per year

At $\mathrm{BMC}$, research is always in progress.

Learn more biomedcentral.com/submissions 